\title{
PERLINDUNGAN HUKUM BAGI PENYEDIA ATAS PENGHENTIAN KONTRAK PENGADAAN BARANG DAN JASA
}

\author{
OLEH : \\ DIMAS TEGAR PALILING \\ MAHASISWA FAKULTAS HUKUM UNIVERSITAS AIRLANGGA
}

\begin{abstract}
ABSTRAK
From the juridical standpoint that there are issues that are not acomodate in the technical regulations for the procurement of goods and services, in this presidential regulation Number 54 year 2010 along with the revised document. In an implementation of the contract for the procurement of goods and services, such as the implementation of the construction made possible the occurrence state of kahar. the goal of the research in this paper is analyzing the meaning of termination of contracts in the procurement of goods and services and analyze the legal consequences of termination of the contract against the execution of a contract for the procurement of goods and services .Research methods used in the writing of scientific papers using normative legal research methods. Research results show that the meaning of termination and termination of Contracts for the procurement of goods and services differs. Termination of the contract is a contract that is caused by the suspension not work power force of the implementation of the contract, but the contract still exist, such as the circumstances of the termination of legal consequences whereas kahar contract is the Provider is entitled to payment for the work that has been done and the user must make payment upon receipt of the goods/services; and the provider is entitled to financial compensation, in unison with the user having to provide financial compensation for the delay in payment, include the clause of the contract to change the determination of the length of time until when the contract is terminated and payout system.
\end{abstract}

Keywords: legal protection, contracts, goods and services. 


\section{A. PENDAHULUAN}

Sesungguhnya perihal yang menyoal tentang pengadaan barang dan jasa masih menyisahkan permasalahan yang menarik untuk dikaji. Hal tersebut banyak ditemui dalam rana praktik maupun secara konsep dalam peraturan perundang-undangan yang berkaitan. Kemudian baru-baru ini di susul dengan keluarnya aturan baru di bidang jasa konstruksi yakni Undang-Undang Nomor 2 tahun 2017 tentang Jasa Konstruksi. Implikasinya bahwa banyak aturan-aturan di bawahnya yang otomatis akan mengikuti/menyesuaikan aturan yang baru ini.

Persoalan-persoalan di atas di antaranya terkait prakontrak, masa kontrak, masa pelaksanaan kontrak hingga pengakhiran kontrak. Salah satu di antara hal-hal ini yang menjadi sorotan yakni tentang hubungan pelaksanaan kontrak dan pengakhiran kontrak. Dalam konteks ini menyinggung tentang penghentian kontrak. Sekaligus hal ini akan menjadi objek kajian penulis.

Ada problematika hukum hasil dari temuan penulis. Problem tersebut dari segi yuridis dan konseptual. Dari segi yuridis bahwa ada persoalan penting yang tidak terakomodasi dalam peraturan teknis pengadaan barang dan jasa, dalam hal ini peraturan Presiden Nomor 54 tahun 2010 berserta perubahannya. Dalam suatu pelaksanaan kontrak pengadaan barang dan jasa, seperti pelaksanaan konstruksi dimungkinkan terjadinya keadaan kahar. Dalam pasal 91 (1) Perpres 54 tahun 2010 dijelaskan bahwa keadaan kahar adalah suatu keadaan yang terjadi diluar kehendak para pihak dan tidak dapat diperkirakan sebelumnya, sehingga kewajiban yang ditentukan dalam Kontrak menjadi tidak dapat dipenuhi.

Hal tersebut berarti dalam keadaan kahar tidak mungkin kontrak akan dilaksanakan secara utuh atau bahkan sampai selesai. Sekalipun secara konsep, kahar dibedakan menjadi 2 (dua), yaitu kahar temporer dan kahar permanen. Kahar temporer yaitu keadaan kahar yang bersifat sementara seperti banjir yang mengakibatkan pelaksanaan tertunda untuk sementara. Sementara kahar permanen adalah keadaan di mana prestasi sama sekali tidak bisa terpenuhi, seperti gempa bumi. Bahkan keadaan kahar tidak lagi dibatasi hanya pada bencana alam, tapi juga bencana non alam ataupun 
keadaan industri lainnya sebagaimana dinyatakan melalui keputusan bersama Menteri Keuangan dan menteri teknis terkait.

Dalam keadaan kahar permanen, maka pelaksanaan kontrak harus dihentikan. Karena keadaan kahar tersebut mengakibatkan perikatan tidak lagi bekerja (werking) walaupun perikatannya sendiri tetap ada. Salah satu pihak tidak dapat menuntut agar perikatan itu dipenuhi dan debitur tidak dapat dikatakan berada dalam keadaan lalai. Prinsipnya, perikatannya masih tetap ada, yang gugur hanyalah daya kerjanya. Hal ini penting apalagi mengenai keadaan kahar yang temporer. Perikatan itu kembali mempunyai daya kerja jika keadaan kahar itu berhenti.

Oleh sebab perikatan tidak dapat bekerja maka pelaksanaan menjadi tidak mungkin. Sehingga bila dipaksakan salah satu pihak akan merugi. Artinya dalam keadaan yang ideal ketika keadaan kahar terjadi maka pihak penyedia berhak mengajukan penghentian kontrak dan berhak mendapat pembayaran sejauh yang prestasi yang telah diselesaikn.

Poin berikutnya yang menjadi permasalahan ialah secara konsep penyedia berhak menghentikan kontrak sementara bilamana pihak PPK belum membayar biaya pelaksanaan sesuai yang diperjanjikan. Tapi secara yuridis, ketentuan peraturan yang berkenan dengan penghentian pelaksanaan kontrak tidak diakomodasi.

Dulu perihal ini ada termuat dalam ketentuan lama, yaitu Keputusan Presiden Nomor 80 tahun 2003. Namun setelah digantikan dan tidak berlaku lagi ketentuan tentang penghentian kontrak tidak dimasukkan. Ini menjadi problem, karena keadaan lapangan memungkinkan terjadinya kahar. Sementara tidak ada dasar hukum untuk melakukan penghentian.

Sekalipun dalam Peraturan Presiden Nomor 54 tahun 2010, Pasal 91 terkait Keadaan Kahar, pada poin ke enam (6) menjelaskan tentang dimungkinkan perubahan kontrak bila terjadi Keadaan Kahar, para pihak dapat melakukankesepakatan, yang dituangkan dalam perubahan kontrak. Namun perubahan kontrak sebagaimana pada pasal 87 perpres 54 tahun 2010 tidak menjelaskan terkait penghentian kontrak secara utuh. Ia hanya menyinggung mengenai penambahan atau Pengurangan volume 
pekerjaan, jenis pekerjaan, pengubahan spesifikasi teknis pekerjaan, sampai pengubahan jadwal pelaksanaan. Esensinya bukan penghentian kontrak.

Akibat dari tidak dimasukkannya pengaturan tentang penghentian kontrak dalam peraturan teknis terkait pengadaan barang dan jasa, memunculkan masalah baru. Masalah itu bersifat konseptual. Seperti yang penulis dapatkan di lapangan, dalam rana praktis terjadi penggunaan istilah yang serampangan. Ada penghentian kontrak yang esensinya pemutusan dan ada pemutusan yang esensinya adalah penghentian kontrak. Dampaknya bahwa pihak yang dirugikan atas keputusan tersebut mengalami kesulitan dalam menegakkan haknya. Ketika pihak penyedia menggugat karena dilakukan pengakhiran kontrak atas dasar pemutusan, ternyata pihak PPK mendalilkan bahwa ini bukan pemutusan tapi penghentian. Karena perpres 54 tahun 2010 hanya menyediakan upaya hukum untuk pemutusan kontrak.

Terlepas bahwa perbedaan penghentian dan pemutusan kontrak ini sifatnya hanya berbeda secara gradual, tapi memiliki akibat hukum yang berbeda. Maka Sehubungan dengan itu, penulis mengangkat isu penghentian kontrak sebagai permasalahan utama. Mengingat istilah penghentian kontrak hanya ada ditemukan dalam Keputusan Presiden Nomor 80 tahun 2003, tapi faktanya hal ini masih dibutuhkan untuk menjamin hak-hak para pihak. Maka dari itu pentingnya memahami makna pemutusan dan penghentian kontrak, lebih khusus dalam sistem pengadaan barang dan jasa.

Adapun tujuan penelitian dalam tulisan ini adalah Menganalisis makna penghentian kontrak dalam Pengadaan Barang dan Jasa dan Menganalisis akibat hukum penghentian kontrak terhadap pelaksanaan kontrak pengadaan barang dan jasa. Manfaat Penelitian adalah Secara teoretik, memberikan masukan ilmu pengetahuan dan ilmu hukum pada umumnya yang berkaitan dengan perlindungan hukum bagi penyedia barang dan jasa atas penghentian kontrak secara sepihak dan Secara Praktis, memberikan sumbangan pengetahuan kepada masyarakat pada umumnya dan dunia akademis pada khususnya mengenai perlindungan hukum atas penghentian kontrak.

\section{B. METODE PENELITIAN}


Metode penelitian yang digunakan dalam penulisan karya ilmiah ini adalah suatu metode yang terarah dan sistematis sebagai cara untuk menemukan, mengembangkan, dan menguji kebenaran sebab nilai ilmiah suatu penelitian selalu beriringan dengan metode penelitian apa yang ia pergunakan. Setiap penulisan tesis harus mengandung suatu kebenaran yang dapat dipertanggungjawabkan, maka diperlukan metode yang sistematis dan terarah sehingga memperoleh hasil sesuai dengan prosedur yang benar. Metode penelitian, pendekatan masalah, sumber bahan hukum, dan analisis bahan hukum harus dilakukan secara benar dan tepat.

Penelitian hukum merupakan suatu proses untuk menemukan aturan hukum, prinsip-prinsip hukum, maupun doktrin-doktrin guna menjawab isu hukum terkait permasalahan hukum yang dihadapi

\section{PEMBAHASAN}

\section{Makna Penghentian Kontrak dalam Pengadaan Barang dan Jasa}

Penghentian kontrak berbeda dengan pemutusan kontrak. Dalam literatur asing, penghentian ini diistilahkan sebagai Suspension dan pemutusan adalah termination. Sehingga secara konseptual makna kedua istilah ini berbeda. Penghentian kontrak lebih dimaknai pada penangguhan. Sementara pemutusan kontrak esensinya adalah putus karena kesalahan. Sekalipun di lapangan kedua istilah ini sering dipakai secara serampangan dan tidak bertanggung jawab.

Tapi, Kamus Besar Bahasa Indonesia memberikan arti yang berbeda secara kedua gradual saja antara pemutusan dan penghentian kontrak. Kedua istilah ini merupakan sinonim. Penghentian adalah keadaan tanpa gerak; halangan;jeda:pemberhentian/pem·ber'hen·ti.an/adalah proses, cara, perbuatan memberhentikan; tempat berhenti;menghentikan/meng.hen.ti·kan/, yakni meminta sesuatu (mobil dan sebagainya) berhenti; menyetop; membuat (menyebabkan), berhenti:ia mobilnya tepat di depan pintu; mengakhiri; menyudahi:ia belumpetualangannya;penghentian/peng·hen·ti·an/adalah halmenghentikan (mengakhiri, menyetop, dan sebagainya).

Sedangkan pemutusan adalah proses, cara, perbuatan memutuskan; penetapan, tidak berhubungan (bersambung) lagi (karena terpotong dan sebagainya). 
Contoh kawat telepon itu putus; habis: modalnya telah putus/habis; selesai; rampung; berakhir: perundingan sudah --; ada kepastian (ketentuan, ketetapan, penyelesaian); mendapat kepastian: sampai sekarang perkaranya belum --; hilang; tidak ada lagi; tidak mempunyai lagi (tentang harapan, pikiran); mendapat; tidak ada hubungan lagi; berpisah (tentang hubungan persahabatan, jalinan cinta, dan sebagainya): hubungan cinta mereka berdua sudah -;

Penghentian merupakan akibat. Karena terputus akhirnya terhenti. Namun berhentinya ini lebih ke keadaan alami. Ia terhenti karena memang faktanya menunjukkan keadaan yang terhenti. Berbeda jika dikatakan terhenti karena dihentikan. Sehingga perbedaan antara penghentian dan pemutusan hanyalah gradual.Penghentian dan Pemutusan dalam perspektif hukum Nomenklatrur penghentian dan pemutusan dapat ditemukan dalam hukum ketenagakerjaan. Menurut Undang-undangNo. 13 Tahun 2003 mengartikan bahwa Pemberhentian atau Pemutusan hubungan kerja adalah pengakhiran hubungan kerja karena suatu hal tertentu yang mengakibatkan berakhirnya hak dan kewajiban antar pekerja dan pengusaha. Pemberhentian juga bisa berarti Pemutusan Hubungan Kerja (PHK) karyawan dari suatu organisasi perusahaan. Pemberhentian yang dilakukan oleh perusahaan harus berdasarkan dengan Undang - undang No 12 Tahun 1964 KUHP. Lalu, pemberhentian juga mesti memperhatikan pasal 1603 ayat 1 KUHP yaitu mengenai "tenggang waktu dan izin pemberhentian". Perusahaan yang melakukan pemberhentian akan mengalami kerugian karena karyawan yang diberhentikan membawa biaya penarikan, seleksi, pelatihan dan proses produksi berhenti.

Dalam keputusan Presiden Nomor 80 tahun 2003 Pasal 35 menjelaskan tentang penghentian dan pemutusan kontrak dalam pengadaan barang dan jasa.

(1) Penghentian kontrak dilakukan bilamana terjadi hal-hal di luar kekuasaan para pihak untuk melaksanakan kewajiban yang ditentukan dalam kontrak, yang disebabkan oleh timbulnya perang, pemberontakan, perang saudara, sepanjang kejadian-kejadian tersebut berkaitan dengan Negara Kesatuan Republik Indonesia, kekacauan dan huru hara serta bencana alam yang dinyatakan resmi oleh pemerintah, atau keadaan yang ditetapkan dalam kontrak. 
(2) Pemutusan kontrak dapat dilakukan bilamana para pihak cidera janji dan/atau tidak memenuhi kewajiban dan tanggung jawabnya sebagaimana diatur di dalam kontrak.

\section{Akibat penghentian kontrak terhadap pelaksanaan barang dan jasa}

Dari segi sebabnya, penghentian kontrak dilakukan karena adanya keadaan di luar kesalahan masing-masing pihak dalam kontrak. Keadaan tersebut dipahami sebagai kahar. Perlu diperhatikan bahwa kahar berbeda dengan hardship. Hardship adalah suatu kedaan di mana kinerja kontrak menjadi lebih berat bagi salah satu pihak, pihak yang tetap terikat melaksanakan kewajibannya "Jadi, para pihak tidak bisa keluar dari kontrak hanya karena menjadi tidak menguntungkan untuk mereka. Sebaliknya, kewajiban kontrak harus dilakukan meskipun perubahan di pasar telah menyebabkan salah satu pihak menjadi lebih berat bagi debitur. Di Amerika Serikat istilah "Hardship" terbatas pada situasi di mana dimungkinkan untuk melakukan kontrak.

Dalam peraturan Jasa Konstruksi, force majeure diartikan sebagai suatu kejadian yang timbul di luar kemauan dan kemampuan para pihak yang menimbulkan kerugian bagi salah satu pihak. Dalam peraturan Pengadaan Barang dan Jasa,force majeure disebut keadaan kahar, artinya suatu keadaan yang terjadi di luar kehendak para pihak sehingga kewajiban yang ditentukan dalam kontrak menjadi tidak dapat dipenuhi. Dalam peraturan Jasa Konstruksi dan peraturan Pengadaan Barang dan Jasa, pembentuk peraturan mewajibkan para pihak untuk memasukkan klausulforce majeure.

Jadi, Hardship lebih menekankan pada keadaan yang tidak seimbang secara mendasar diantara pihak, sedangkan force majeure memiliki pengertian lebih umum yang menunjuk pada peristiwa-peristiwa tak terduga di luar kekuasaan para pihak.Akibat hukum dari force majeure absolute menyebabkan pemenuhan prestasi tidak mungkin dapat dilakukan lagi dan seketika itu kontrak putus, sedangkan akibat hukum dari hardship terhadap kontrak terutama menyangkut pada kesempatan pihak yang dirugikan untuk mengajukan negosiasi ulang (renegosiasi).

Sebelumnya telah diurai bahwa force majeur atau keadaan memaksa/kahar dibedakan menjadi kahar yang bersifat temporer dan kahar permanen. Kahar yang bersifat temporer mensyaratkan kejadian yang berlangsung untuk beberapa saat saja. Misalnya banjir, demo, pemadaman listrik. Maka setelah peristiwa kahar terjadi, 
pelaksanaan kontrak dapat kembali dilanjutkan. Lain halnya dengan kahar permanen yang sifat kejadiannya paten dan berlangsung dalam periode yang lama, seperti tsunami, gempa bumi.

Untuk peristiwa kahar temporer, maka akan dilakukan penghentian kontrak. Akibatnya adalah pelaksanaan kontrak ditangguhkan. Dalam hal ini yang tidak bekerja hanyalah pelaksanaannya, tapi kontraknya tetap ada. Akibat dari penghentian kontrak ini adalah

- Penyedia berhak mendapatkan pembayaran atas pekerjaan yang telah dilakukan dan pengguna harus melakukan pembayaran atas barang/jasa yang diterimanya; dan

- Penyedia berhak mendapatkan ganti rugi finansial, berbarengan dengan itu Pengguna harus memberikan ganti rugi finansial atas keterlambatan pembayaran

- Mencantumkan klausula perubahan kontrak untuk penetapan jangka waktu sampai kapan kontrak dihentikan dan sistem pembayarannya.

Sementara untuk kahar permanen, akibat hukumnya hampir sama dengan di atas. Cuma dalam kasus ini tanpa perlu mencantumkan penetapan jangka waktu sampai kapan kontrak dihentikan mengingat sifat keadaannya permanen. Jadi bukan hanya pelaksanaannya yang terhenti tapi kontraknya. Akibat hukum ini juga berlaku untuk penghentian kontrak yang disebabkan oleh karena perintah Undang-Undang (tidak didasari oleh kesalahan masing-masing pihak). Untuk keadaan ini, diberikan kebebasan kepada pemerintah sebagai wakil badan hukum pemerintah untuk memilih apakah menghentikan untuk sementara atau memberhentikan secara permanen

\section{Upaya Hukum Bagi Penyedia}

Karena kajian ini menyangkut perlindungan hukum, maka seyogyianya direkomendasikan upaya perlindungan hukum bagi penyedia. Kontrak pengadaan barang dan jasa dalam ketentuannya dihadirkan untuk melaksanakan tujuan bernegara, secara khusus mensukseskan kelancaran pengadaan bagi pedmerintah. Jadi semangat ketentuannya baik itu Undang-Undang Jasa Konstruksi maupun Peraturan Presiden berserta perubahannya diperuntukkan terhadap kepentingan pemerintah.

Tapi perlu diketahui bahwa pengadaan barang dan jasa pemerintah juga harus diselenggarakan berdasarkan prinsip-prinsip keadilan dan kebenaran. Tidak boleh 
boleh menegasikan hak-hak penyedia. Kontrak pengadaan berada dalam rezim privat, olehnya diikat dengan beberapa ketentuan seperti Burgelijk Wetboek. Lepas bahwa pemerintah merupakan satu entitas publik tapi dalam hal ini ia bertindak sebagai wakil badan hukum negara yang mempunyai kepentingan. Dan kepentingannya disini menggunakan sarana hukum privat, yaitu kontrak. Maka pemerintah harus tunduk pada aturan hukum privat.

Dalam hal penyedia merasa dirugikan dalam konteks penghentian kontrak, upaya hukum yang diajukan adalah memohon perubahan kontrak kepada PPK untuk segera dilakukan penghentian kontrak. Dalam hal PPK melanggar ketentuan kontrak, maka penyedia mengajukan tuntutan terhadap PPK atas dasar wanprestasi. Karena pelanggaran yang menyangkut tidak diberikannya hak yang pantas terhadap penyedia merupakan pelanggaran kontraktual.

\section{PENUTUP}

Adapun kesimpulan dari uraian pada pembahasan yang telah di jelaskan pada bab sebelumnya adalah sebgai berikut:

1. Makna penghentian dan Pemutusan Kontrak Pengadaan Barang dan Jasa berbeda. Penghentian kontrak adalah penangguhan kontrak yang disebabkan oleh tidak berlakunya daya kerja pelaksanaan kontrak, tetapi kontraknya tetap ada, seperti keadaan kahar. Sementara pemutusan kontrak membawa makna adanya kesalahan/kelalaian. Jadi pemutusan kontrak dilakukan oleh penyedia karena adanya kesalahan/kelalaian dari pihak penyedia.

2. Akibat hukum penghentian kontrak adalahPenyedia berhak mendapatkan pembayaran atas pekerjaan yang telah dilakukan dan pengguna harus melakukan pembayaran atas barang/jasa yang diterimanya; dan Penyedia berhak mendapatkan ganti rugi finansial, berbarengan dengan itu Pengguna harus memberikan ganti rugi finansial atas keterlambatan pembayaran, Mencantumkan klausula perubahan kontrak untuk penetapan jangka waktu sampai kapan kontrak dihentikan dan sistem pembayarannya. 


\section{DAFTAR PUSTAKA}

\section{Buku:}

Badrulzaman, Mariam Darus, 1998, Perjanjian dengan Pemerintah (Government Contract), dalam hukum kontrak Indonesia, Elips: Jakarta.

Bruggink, J.J.H., 1996, Refleksi Hukum-alih bahasa Arief Sidharta, Citra Aditya Bakti: Bandung.

Hartkamp, Arthur S, 1995, Contract Law in the Netherlands, Kluwer Law International The Hague: London-Boston

Hernoko, Agus Yudha, 2010, Hukum Perjanjian Asas Proporsionalitas dalam Kontrak Komersial, Kencana Prenada Media Group, Jakarta

Peter Mahmud Marzuki, 2008, Penelitian Hukum, Kencana: Jakarta.

S.B. Marsh and J. Soulsby, alih bahasa Abdulkadir, 2006, Business Law Hukum Perjanjian, PT Alumni: Bandung.

Saragih, D. 1998, Pembentukan Hukum Kontrak menurut BW baru Belanda dalam Hukum Kontrak Indonesia (Seri Dasar Hukum Ekonomi 5), Elips: Jakarta.

Simamora, Yohanes Sogar, Hukum Kontrak, Kontrak Pengadaan Barang dan Jasa Pemerintah di Indonesia, Kantor Hukum Wins \& Partners: Surabaya.

Sofwan, Sri Soedaewi Masjchoen, 1980, Hukum Perdata (Hukum Perutangan-Bagian A), Fakultas Hukum Universitas Gadjah Mada: Yogyakarta.

Subekti, 1996, Hukum Perjanjian, Internusa: Jakarta.

Subekti, 1995, Aneka Perjanjian, Citra Aditya Bakti: Bandung.

Jurnal:

Peter Mahmud Marzuki, 2003, Batas-batas Kebebasan Berkontrak, Yuridika: Surabaya.

\section{Perundang-Undangan:}

Burgelik Wetboek (B.W.), S. 1847-23, terjemahan R. Subekti dan R. Tjitrosudibio, 1995, Pradnya Paramitha: Jakarta.

Undang-Undang Dasar Negara Republik Indonesia Tahun 1945;

Undang-Undang Nomor 2 tahun 2017 tentang Jasa Konstruksi;

Undang-Undang Nomor 18 tahun 1999 tentang Jasa Konstruksi;

Undang-undang Nomor 17 tahun 2003 tentang Keuangan Negara; 
Undang-Undang Nomor 1 tahun 2004 tentang Perbendaharaan Negara;

Peraturan Pemerintah Republik Indonesia Nomor 43 tahun 2013 tentang Tata Cara Pelaksanaan Anggaran Pendapatan dan Belanja Negara;

Peraturan Presiden Nomor 54 tahun 2010 tentang Pengadaan Barang/Jasa Pemerintah;

Peraturan Presiden Nomor 35 tahun 2011 tentang Perubahan Pertama atas Peraturan Presiden Nomor 54 tahun 2010 tentang Pengadaan Barang/Jasa;

Peraturan Presiden Nomor 70 tahun 2012 tentang Perubahan Kedua atas Peraturan Presiden Nomor 54 tahun 2010 tentang Pengadaan Barang/Jasa;

Peraturan Presiden Nomor 172 tahun 2014 tentang perubahan Ketiga atas Peraturan Presiden Nomor 54 tahun 2010 tentang Pengadaan Barang dan Jasa;

Peraturan Presiden Nomor 4 tahun 2015 tentang perubahan Keempat atas Peraturan Presiden Nomor 54 tahun 2010 tentang Pengadaan Barang/jasa;

Peraturan Presiden Nomor 157 tahun 2014 tentang Perubahan atas Peraturan Presiden Nomor 106 tahun 2007 tentang Lembaga Kebijakan Pengadaan Barang/Jasa Pemerintah;

Peraturan Kepala Lembaga kebijakan Pengadaan Barang/Jasa Pemerintah Nomor 12 tahun 2011 tentang Pedoman Umum Perencanaan Pengadaan Barang/Jasa Pemerintah;

Peraturan Kepala Lembaga kebijakan Pengadaan Barang/Jasa Pemerintah Nomor 5 tahun 2012 tentang Unit Layanan Pengadaan;

Peraturan Kepala Lembaga kebijakan Pengadaan Barang/Jasa Pemerintah Nomor 13 tahun 2012 tentang Pengumuman Rencana Umum Pengadaan Barang/Jasa Pemerintahan. 